\title{
Makespan reduction using dynamic job sequencing combined with buffer optimization applying genetic algorithm in a manufacturing system
}

\author{
Sharath C.H. Somashekhara ${ }^{1 *}$, Arun K.Y. Setty ${ }^{2}$, Srinath M. Sridharmurthy ${ }^{2}$, Poornima Adiga ${ }^{3}$, Ulavathi S. Mahabaleshwar ${ }^{4}$, \\ Giulio Lorenzini ${ }^{5}$ \\ ${ }^{1}$ Department of Mechanical Engineering, NMAMIT Nitte, India \\ ${ }^{2}$ Industrial \& Production Engineering, MCE Hassan, India \\ ${ }^{3}$ Industrial Engineer, HCL Technologies, Bangalore, India \\ ${ }^{4}$ Department of Mathematics, Government First Grade College for Women, Hassan 573 202, India \\ ${ }^{5}$ Department of Engineering and Architecture, University of Parma, Parco Area delleScienze, Italy
}

Corresponding Author Email: sharathchandrahs@ @itte.edu.in

https://doi.org/10.18280/mmep.060104

Received: 21 September 2018

Accepted: 8 February 2019

\section{Keywords:}

conveyor system, diverging conveyor, dynamic sequencing, job sequencing, work optimization

\begin{abstract}
The advancement in the computer technologies and its integration with the production system has become highly flexible to produce large family of products. One of the main objectives of flexibility is to reduce the setup cost and time to respond to the market demands. Even the most flexible system may invite some setup cost in job changes, it is often desirable to change the sequence of jobs to further reduction in the setup cost and its related time. In the present work, the influence of dynamic job sequencing on a diverging junction conveyor production line with the objective to save the production cost $\&$ time have been presented. A production line which produces different variety of jobs is considered, where the raw part of different jobs arrives from the source randomly. Each batch of job has to undergo different processing operations. A production line is modelled and simulated using various production elements and its influence on reducing the manufacturing time is presented. The object oriented, discrete event simulation software is used to model and simulate the production system. It has been observed that dynamic sequencing of the jobs reduces the processing time by an average of $17 \%$.
\end{abstract}

\section{INTRODUCTION}

A conveyor system is mechanical handling equipment that is used to move components from initial position to a desired position. Conveyor system is used to transport materials quick and efficiently making it very popular in material handling and packaging during high volume production. Conveyors can transfer large amount of material with simple motion control and also provide buffer space. When it comes to conveyor technologies, poor product handlings are the enemies of efficiency. Product handling problems can also impact efficiency, increase waste and disable desired production rates to be achieved consistently. This can be minimized by proper simulation techniques. The problem of optimization of production using conveyors can be efficiently done using a simulation software to reduce make span (total time), change over's and cost.

Over the last two decades various approaches have been attempted for dynamic scheduling of jobs in different production system. Narumol\& Carlos [1] found the impact of parallel processing on job sequences inflexible assembly systems in which parallel processing offers several advantages. However, when processing times are allowed to vary, it can result in unpredictable job sequences. The researchers analysethe job sequencing after parallel processing and provides strategies for dealing with jobs getting out of sequence. Bolat [2] worked on sequencing jobs on an automobile assembly line with objectives and procedures.
Xuefeng \& Balaram [3] proposed a multi-agent scheduling system with a good solution quality and robustness with routing flexibility and sequence-dependent setup. Matsuuraet al. [4] studied the problem of selection between sequencing and dispatching as a scheduling approach in a job-shop setting, Later, Hwang \& Choi [5] proposed a workflow-based dynamic scheduling framework, in which a work flow management system (WFMS) serves as a dynamic job-shop scheduler. Vinod \& Sridharan [6] developed simulation-based Meta models for scheduling a dynamic job shop with sequencedependent setup times. Lou et al. [7] proposed a distributed scheduling approach in which a multi-agent solution towards a 'task-machine' assignment is presented. Renna [8] solved the job shop scheduling problem in cellular manufacturing systems. Márcio et al. [9] developed asynchronous teams for joint lot-sizing and scheduling problem in flow shops. Iris \& Héctor [10] studied on the sequencing dynamic storage systems with multiple lifts and shuttles which is concerned with the scheduling problem of these two lifts, i.e. which lift is going to handle which (storage or retrieval) request, and in which order. Damien et al. [11] did the benchmarking flexible job-shop scheduling and control systems. Benchmarking is comparing the output of different systems for a given set of input data in order to improve the system's performance. The researcher paper proposes a benchmark system based on a real production cell. Yuri [12] presents a dynamic Pareto-optimal method for flexible job shop scheduling based on two criteria simultaneously. Saidi et al. [13] studied the Job Shop 
Scheduling Problem (JSSP) considering the transportation times of the jobs from one machine to another. Jürgen et al. [14] worked on loading and sequencing heuristics for job scheduling on two unrelated parallel machines with long, sequence-dependent set-up times. Ji-Su et al. [15] recapitulated materialistic algorithms to minimize the total family flow time for job-shop scheduling with job families and sequence-dependent set-ups. Mahdi et al. [16] proposed a simulation optimization approach for real-time scheduling in an open shop environment using a composite dispatching rule.

A buffer is used to store job while it is being transferred from one station to the other. Leisten [17] presented a systematic overview of how to formulate flow shop problems with limited buffer storage as well as several heuristics to compete with different class of problems. Park \& Steudel [18] proposed a model for determining job throughput times for manufacturing flow line work cells with finite buffers. Bolat [19] worked on sequencing jobs for an automated manufacturing module with buffer. Sharadapriyadarshini \& Rajendran [20] formulated the scheduling in a bufferconstrained flow shop and flow line-based manufacturing cell with different buffer-space requirements for jobs. Solimanpur et al. [21] investigated the flow shop group scheduling with limited buffers to minimise the total completion time.

Kamali et al. [22] examined the abilities and limitations of combined utilization of humans, automation, conveyors and robots and also did the case study which is used to illustrate the usefulness and efficiency of the proposed approach to systems optimization. Then Buzacott [23] developed the models which explain why new automobile assembly systems are abandoning traditional moving assembly line concepts if human operators perform most of the tasks and to illustrate these problems and the effect of alternative part delivery systems and the impact of job re-sequencing requirements. Later, John \& Ranky [24] developed the Object concerned with the modelling and design of reconfigurable conveyors in flexible assembly systems in spite of their inflexibility, cost and often complex customization requirements, most manual or robotized assembly systems in industry employ some sort of conveyor systems.
It is observed from the above literature that various work on different production systems were carried out to achieve productivity. However, there is no specific work addressing dynamic sequencing on different variations of a mixed model production system. This creates a lot of scope for research in this domain. Therefore, this paper addresses the multilevel job sequencing on a different variations of diverging conveyor system and its effect on the total manufacturing time.

\section{METHODOLOGY}

\subsection{Problem statement}

A multi-level general hypothetical model is defined for a diverging conveyor system. In order to show the significance of sequencing, the initial production line is shown where the processing work is carried out without sequencing later the production line is added with the buffer of some random capacity without sequencing and then the sequencing logic is added to the buffer, which shows the significance of sequencing of jobs. The parameter which evaluates the significance is the total manufacturing time of the production line at various levels.

\subsection{Description of initial production line without buffer}

Figure 1 shows an initial layout of the diverging conveyor system. In this layout the there are five processing stations (Station-1 to Station-5) through which the jobs are routed based on the type of the layout and then diverge to different operations from the diverging points. There is different scenario of layout for the Figure 1 and are listed in the Table 1. The common physical specification details of the layout are shown in the Table 2. The brief description of the individual layout is discussed in the following sections. In all types of layouts, the arrival of different jobs from the source is considered as random.

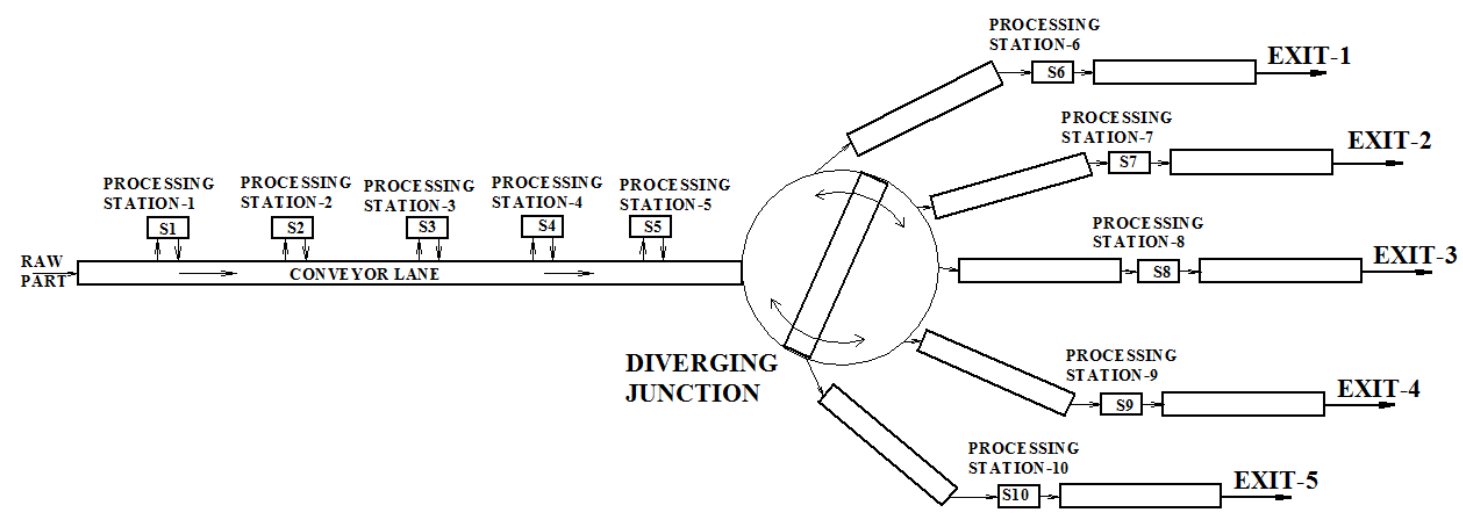

Figure 1. Initial layout of the diverging conveyor production line

Table 1. Description of different types of layout

\begin{tabular}{cl}
\hline Type & \multicolumn{1}{c}{ Description } \\
\hline Layout- & $\begin{array}{l}\text { All jobs will be undergoing the common processing } \\
\text { operations from Station-1 to Station-5 and then } \\
\text { diverge to different operations from the diverging } \\
\text { points. The processing and setup time of processing } \\
\text { station is same throughout the line. }\end{array}$ \\
\hline
\end{tabular}

\begin{tabular}{cl}
\hline $\begin{array}{c}\text { Layout- } \\
1.2\end{array}$ & $\begin{array}{l}\text { Like layout-1.1 all jobs will undergo the common } \\
\text { processing operations from Station-1 to Station-5 } \\
\text { and then diverge to different operations but the } \\
\text { processing and setup time in processing stations is } \\
\text { different for each job. }\end{array}$ \\
\hline $\begin{array}{l}\text { Layout- } \\
1.3\end{array}$ & $\begin{array}{l}\text { In this layout the jobs are routed to different selective } \\
\text { stations between Station-1 to Station-5 and also the } \\
\text { processing and setup time for each job is different } \\
\text { for different processing stations. }\end{array}$ \\
\end{tabular}


Table 2. Common physical specification details

\begin{tabular}{cc}
\hline Type & Description \\
\hline Total processing stations & 10 \\
\hline Length assumed for each conveyor & $5 \mathrm{~meters}$ \\
\hline Travelling speed of jobs on conveyors & $1 \mathrm{~m} / \mathrm{s}$ \\
\hline
\end{tabular}

\subsection{Description of layout-1.1}

In the layout 1.1 which is shown in the Figure 1the jobs will undergo processing operation of 10 minutes through all stations, which will be having setup time of 3 minutes. The setup time and processing operation time is assumed to be same for all stations. The jobs will undergo common processing operations from station-1 to station-5 and then diverge to final processing operations. It is also assumed that there are 10 batches (varieties) of jobs and total number of jobs is 150 in the layout 1.1 and it is assumed that the processing operation after the diverging point is different than before diverging point and the processing station which are after diverging point can perform two different operations without any requirement of the changing in the setup.

\subsection{Description of Layout-1.2}

Table 3. Processing and setup time for each job in the Layout 1.2

\begin{tabular}{ccc}
\hline Jobs & $\begin{array}{c}\text { Processing Time } \\
\text { (Minutes: Seconds) } \\
\text { Job1 }\end{array}$ & $\begin{array}{c}\text { Setup Time } \\
\text { (Minutes: Seconds) } \\
3: 13.3237\end{array}$ \\
\hline Job2 & $7: 56.4706$ & $3: 10.5644$ \\
\hline Job3 & $8: 28.7370$ & $3: 00.7343$ \\
\hline Job4 & $9: 17.9881$ & $3: 06.8860$ \\
\hline Job5 & $7: 49.9811$ & $2: 53.8303$ \\
\hline Job6 & $10: 18.4653$ & $2: 56.7617$ \\
\hline Job7 & $11: 00.6493$ & $2: 52.0552$ \\
\hline Job8 & $9: 53.8227$ & $2: 48.2532$ \\
\hline Job9 & $9: 16.8441$ & $2: 40.5041$ \\
\hline Job10 & $9: 04.4996$ & $2: 29.3058$ \\
\hline
\end{tabular}

In the layout 1.2 the arrangement of the production setup is same as the initial layout which is shown in Figure 1. The jobs will undergo common processing operation from station-1 to station- 5 and then diverge for the different operations after the diverging point. The layout 1.1 can be considered as the ideal production line where there are no variations in the processing operations, but practically there will be some variations since it is manually operated and may vary depending on the operator working efficiency. This factor is considered in the layout 1.2 and slight variation in the setup and processing operations is taken into considerations for each processing station. The variations are modelled as the erlang distributions. The processing and setup time for each job is shown in the Table 3.

\subsection{Description of Layout-1.3}

The physical setup of the layout 1.3 is same as the initial layout which is shown in the Figure 1. In order to study the effect of sequencing, a slight variation in the layout is considered in which only the selected jobs are sequenced at the selected stations and the jobs to be processed through processing stations are shown in the Table 4. Depending on the processing route the selected jobs are processed between Station-1 to Station-5 and finally diverge after the diverging junction. The randomness in the setup and processing stations is also taken into consideration which is same as the layout 1.2 shown in the Table 3.

Table 4. Processing route of the jobs in the layout 1.3

\begin{tabular}{cc}
\hline Stations & Jobs \\
\hline 1 & $\mathrm{~J}_{1}, \mathrm{~J}_{3}, \mathrm{~J}_{5}, \mathrm{~J}_{7} \& \mathrm{~J}_{9}$ \\
\hline 2 & $\mathrm{~J}_{2}, \mathrm{~J}_{4}, \mathrm{~J}_{6}, \mathrm{~J}_{8} \& \mathrm{~J}_{10}$ \\
\hline 3 & $\mathrm{~J}_{1}, \mathrm{~J}_{2}, \mathrm{~J}_{3}, \mathrm{~J}_{4} \& \mathrm{~J}_{10}$ \\
\hline 4 & $\mathrm{~J}_{4}, \mathrm{~J}_{5}, \mathrm{~J}_{6} \& \mathrm{~J}_{8}$ \\
\hline 5 & $\mathrm{~J}_{1}, \mathrm{~J}_{4}, \mathrm{~J}_{6}, \mathrm{~J}_{7} \& \mathrm{~J}_{10}$ \\
\hline
\end{tabular}

\subsection{Diverging conveyor system with buffer}

Figure 2 illustrates the diverging conveyor system with the buffer storage. As per the observation in the layout 1.1, $1.2 \&$ 1.3 there will be jobs waiting for the processing operations in the conveyors. This demands the buffer to be installed at each station which can hold the jobs and also alter the sequence of jobs coming into it. This installation effect is studied on the total manufacturing time. The new layouts with buffer are renamed as Layout-2.1, $2.2 \&$ 2.3. The description of each layout is shown in the Table 5 .

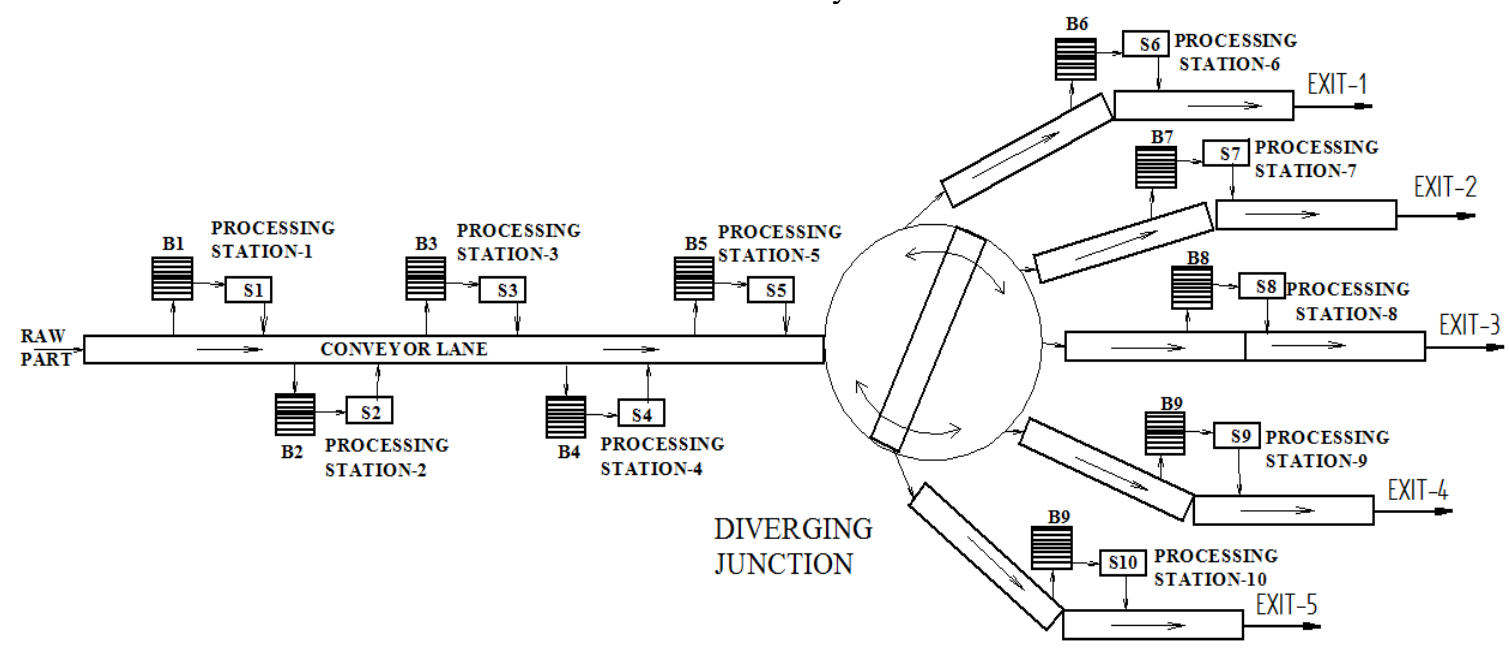

Figure 2. Diverging conveyor system with buffer storage 
Table 5. Description of the diverging conveyor layouts with buffer

\begin{tabular}{|c|c|}
\hline Type & $\begin{array}{r}\text { Description } \\
\end{array}$ \\
\hline $\begin{array}{c}\text { Layout- } \\
2.1\end{array}$ & $\begin{array}{l}\text { All jobs will be undergoing the common processing } \\
\text { operations from Station- } 1 \text { to Station- } 5 \text { and then } \\
\text { diverge to different operations from the diverging } \\
\text { points. The processing and setup time of processing } \\
\text { station is same throughout the line. The jobs will } \\
\text { enter the buffer and then go for processing } \\
\text { operation to the processing stations. When } \\
\text { sequencing strategy is applied to the buffer the jobs } \\
\text { will exit as the sequence strategy. }\end{array}$ \\
\hline $\begin{array}{c}\text { Layout- } \\
2.2\end{array}$ & $\begin{array}{l}\text { Like layout- } 2.1 \text { all jobs will undergo the common } \\
\text { processing operations from Station- } 1 \text { to Station- } 5 \\
\text { and then diverge to different operations but the } \\
\text { processing and setup time in processing stations is } \\
\text { different for each job. The jobs will enter the buffer } \\
\text { and then go for processing operation to the } \\
\text { processing stations. When sequencing strategy is } \\
\text { applied to the buffer the jobs will exit as the } \\
\text { sequence strategy. }\end{array}$ \\
\hline $\begin{array}{c}\text { Layout- } \\
2.3\end{array}$ & $\begin{array}{l}\text { In this layout the jobs are routed to different } \\
\text { selective stations between Station- } 1 \text { to Station- } 5 \\
\text { and also the processing and setup time for each job } \\
\text { is different for different processing stations. The } \\
\text { jobs will enter the buffer and then go for processing } \\
\text { operation to the processing stations. When } \\
\text { sequencing strategy is applied to the buffer the jobs } \\
\text { will exit as the sequence strategy. The jobs will } \\
\text { enter the buffer as per the route sheet before } \\
\text { undergoing processing operations. }\end{array}$ \\
\hline
\end{tabular}

\subsection{Sequencing logic's adapted in buffer}

\subsubsection{Logic-1}

The buffer can change the sequence of job so that the manufacturing time is reduced. In the sequencing logic each job is assigned and integer value $\mathrm{J}_{\mathrm{i}}$ where $\mathrm{i}=1,2,3 \ldots \ldots 10$. The jobs are let-out in the ascending order so that the job with the least number enters the processing stations and after the processing is complete if the same job is present that will be entering the processing station. When this happens, the setup remains the same because of the same job attributes and thus not requiring the additional setup operations so the processing stations can start with direct processing operations. If same job is not available in the buffer the next job in ascending order will enter the processing station which requires the setup operation. The sequencing logic in brief is shown inTable 6 .

Table 6. Sequencing logic 1 adapted in buffer

\begin{tabular}{cc}
\hline $\begin{array}{c}\text { Jobs before entering the } \\
\text { buffer }\end{array}$ & $\begin{array}{c}\text { Jobs coming out of the } \\
\text { buffer after sequencing }\end{array}$ \\
\hline $\mathrm{J}_{1}, \mathrm{~J}_{2}, \mathrm{~J}_{3}, \mathrm{~J}_{1}, \mathrm{~J}_{5}, \mathrm{~J}_{4}, \mathrm{~J}_{9}, \mathrm{~J}_{7}, \mathrm{~J}_{6} \& \mathrm{~J}_{8}$, & $\mathrm{J}_{1}, \mathrm{~J}_{1}, \mathrm{~J}_{2}, \mathrm{~J}_{3}, \mathrm{~J}_{4}, \mathrm{~J}_{5}, \mathrm{~J}_{6}, \mathrm{~J}_{7}, \& \mathrm{~J}_{8}$ \\
\hline
\end{tabular}

\subsubsection{Logic- 2}

In this logic the jobs are sent in the descending order and its effect on the total simulation time is studied. The logic in brief is shown in the Table 7.

Table 7. Sequencing logic 2 adapted in buffers

\begin{tabular}{cc}
\hline $\begin{array}{c}\text { Jobs before entering the } \\
\text { buffer }\end{array}$ & $\begin{array}{c}\text { Jobs coming out of the } \\
\text { buffer after sequencing }\end{array}$ \\
\hline $\mathrm{J}_{1}, \mathrm{~J}_{2}, \mathrm{~J}_{3}, \mathrm{~J}_{1}, \mathrm{~J}_{5}, \mathrm{~J}_{4}, \mathrm{~J}_{9}, \mathrm{~J}_{7}, \mathrm{~J}_{6} \& \mathrm{~J}_{8}$, & $\mathrm{J}_{9}, \mathrm{~J}_{8}, \mathrm{~J}_{7}, \mathrm{~J}_{6}, \mathrm{~J}_{5}, \mathrm{~J}_{4}, \mathrm{~J}_{3}, \mathrm{~J}_{2}, \mathrm{~J}_{1} \& \mathrm{~J}_{1}$ \\
\hline
\end{tabular}

\subsubsection{Logic-3}

In this logic any job $\mathrm{J}_{\mathrm{i}}$ will enter the processing station; the buffer will search that job Ji, in it. If the $\mathrm{Ji}$ is available that will enter the processing station if it is not present then next random job will enter the processing station. The logic in brief is shown in the Table 8 .

Table 8. Sequencing logic 2 adapted in buffers

\begin{tabular}{cc}
\hline $\begin{array}{c}\text { Jobs before entering the } \\
\text { buffer }\end{array}$ & $\begin{array}{c}\text { Jobs coming out of the buffer } \\
\text { after sequencing }\end{array}$ \\
\hline $\mathrm{J}_{1}, \mathrm{~J}_{2}, \mathrm{~J}_{3}, \mathrm{~J}_{1}, \mathrm{~J}_{5}, \mathrm{~J}_{4}, \mathrm{~J}_{9}, \mathrm{~J}_{7}, \mathrm{~J}_{6} \& \mathrm{~J}_{8}$, & $\mathrm{J}_{1}, \mathrm{~J}_{1}, \mathrm{~J}_{2}, \mathrm{~J}_{3}, \mathrm{~J}_{5}, \mathrm{~J}_{4}, \mathrm{~J}_{9}, \mathrm{~J}_{7}, \mathrm{~J}_{6} \& \mathrm{~J}_{8}$ \\
\hline
\end{tabular}

\subsection{Diverging conveyor system with robot}

Now a day's most of the manufacturing firm are facing shortage of labour's and also firm sometime cannot hire the labour force due to high cost of the labour. If the product of the firm turns out profitable then it would justifiable to invest on robots. The robot does the work of labor of loading and unloading of jobs from the stations and picking of the semi/finished jobs from the conveyor. The Figure 3 shows the layout of the diverging conveyor system with robot, which is the fully integrated automated system compared to provious type. Where $R_{i}(i=1,2,3,4 \& 5)$ represents the pick and place robot at the respective processing stations.

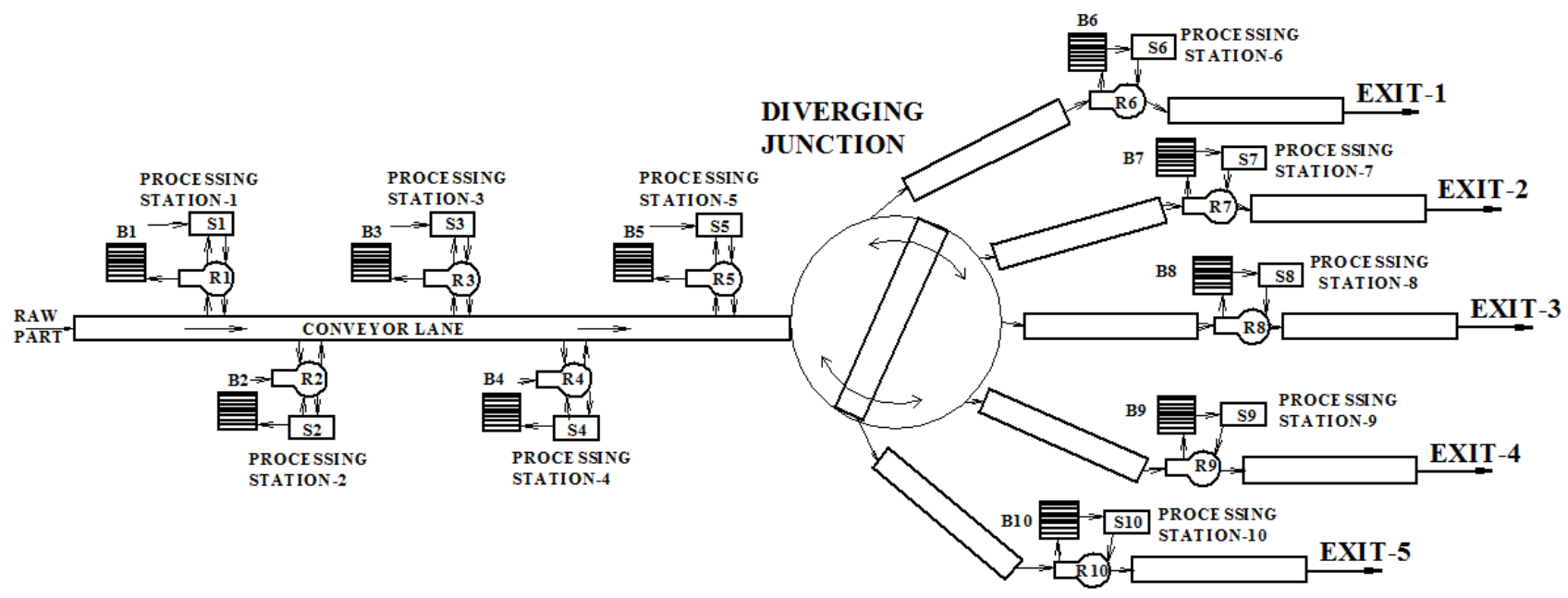

Figure 3. Diverging conveyor system with robot 


\subsubsection{Working of pick \& place robot}

The robot picks the incoming job from the conveyor system, if the processing station is idle the robot directly loads the job into the processing station or if the processing station is occupied it stores the job in the buffer. After the processing is complete in the processing station the robot unloads the job from it and places on the conveyor system, then the robots pick the job as per the exit strategy discussed earlier and loads the next job on the processing station and the cycle repeats till the last job. The Figure 4 shows the working of the robot across the production line.

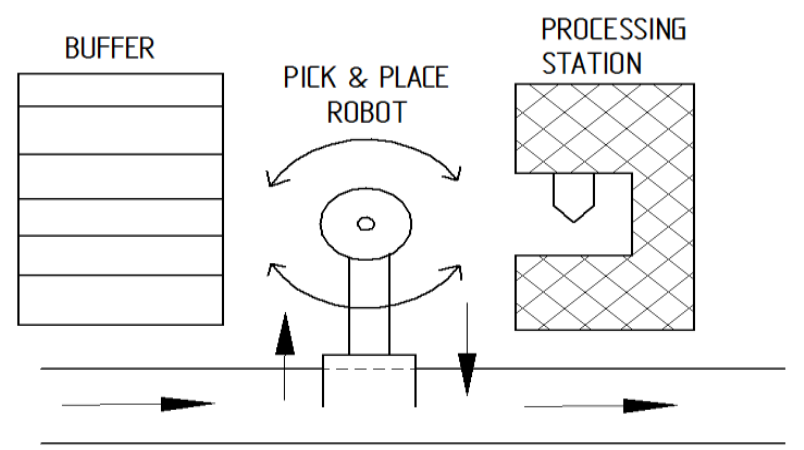

Figure 4. Working of the robot in the production line

\subsection{Distributions used in the model}

\subsubsection{Poisson distribution}

The Poisson-distribution is a discrete distribution. The realizations are non-negative integer numbers. It can be used when the modelling task requires a random number of events. Here the arrival time of the job from the source is modeled as the possion distribution.

\subsubsection{Erlang distribution}

The Erlang-distribution is the sum of $\mathrm{k}$ independent, exponentially distributed random numbers with the parameter beta. Here, randomness for processing and set-up times follows the erlang distribution.

\section{MATHEMATICAL MODEL OF THE LAYOUTS}

\subsection{Layout with constant setup \& machining time}

In this layout the machining and setup time is constant, the mathematical model showing the total manufacturing lead time (MLT) is given by

$\mathrm{MLT}=n_{0}\left(T_{s u}+Q T_{c}+T_{r}+T_{h}\right)$

where,

$\mathrm{n}_{\mathrm{o}}=$ Number of processing station

$\mathrm{T}_{\mathrm{su}}=$ Setup time in processing station in minutes

$\mathrm{Q}=$ Total quantity of job in a batch

$\mathrm{T}_{\mathrm{c}}=$ Cycle time of each job in minutes

$\mathrm{T}_{\mathrm{r}}=$ Transfer time in minutes

$\mathrm{T}_{\mathrm{h}}=$ Handling time of job at each station
When buffer is added to the production line the mathematical model showing total MLT is given by

$M L T=n_{0}\left(T_{s u}+Q T_{c}+T_{y}+T_{h}\right)+T_{b \mathrm{i}}$

where, $\mathrm{T}_{\mathrm{bi}}=$ Job waiting time in buffer which are to be processed. Eq (2). also includes the handling time \& transfer time of robot when used.

\subsection{Layout considering randomness of job with different routes}

The equation for the layout which is having different processing \&setup time which considers randomness for a corresponding processing station's is given by,

$M L T_{f}=\sum_{i=1}^{150}\left(T_{\text {sujik }}+Q_{j} T_{\text {cjik }}+T_{\text {nojik }}\right)$

Where,

$\mathrm{MLT}_{\mathrm{j}}=$ Manufacturing lead time for job $\mathrm{j}(\mathrm{j}=1$ to 150$)$ (min). $\mathrm{T}_{\text {sujk }}=$ Setup time for operation" $\mathrm{i}$ " in a station $\mathrm{k}(\mathrm{min})$.

$\mathrm{Q}_{\mathrm{j}}=$ Quantity of job being processed ( $\mathrm{pc}$ ).

$\mathrm{T}_{\mathrm{cjik}}=$ Operation cycle time for operation " $\mathrm{i}$ " in the station $\mathrm{k}$.

$\mathrm{T}_{\text {nojik }}=$ Non-operation time associated with operation " $\mathrm{i}$ "in a machine $\mathrm{k}$, non-operation time includes transfer \& handling time of job on conveyors.

The same Eq (3). also holds good for the jobs which are having different route considering randomness.

When buffer is added to all stations the equation is given by,

$M L T_{j}=\sum_{i=1}^{150}\left(T_{\text {sujik }}+Q_{j} T_{\text {cjik }}+T_{\text {nojik }}\right)+T_{b k}$

$\mathrm{T}_{\mathrm{bk}}=$ Waiting time of the job in buffer at the corresponding $\mathrm{k}$ machine. Eq (4). also includes the handling time \& transfer time of robot when used.

\section{RESULTS \& DISCUSSIONS}

\subsection{Observations from the layouts $1.1,1.2 \& 1.3$}

The total simulation time of layout $1.1,1.2 \& 1.3$ is shown in the Table 9. It is being observed from the simulation that there will be bottle neck at processing station-1 because the jobs arrive as first in first out (FIFO) and jobs will be waiting for its turn to process. In the layout $1.1 \& 1.2$ all jobs are having common processing operations up to station- 5 . The simulation time of the layout 1.2 is less than the layout 1.1 because layout 1.2 considers the variations in the setup and processing station which may be fast or slow depending on the operator's efficiency. Whereas in the layout 1.3 each job is having different processing operation, so the jobs will be waiting ideally at processing station's even though it may or not required for processing, which in turn increases the total manufacturing. If we introduce a buffer for holding the jobs temporarily between processing and which also has got the provision to change the sequence of jobs, there will be change in the total manufacturing lead time in the layouts. The percentage of working, setup \& waiting portion of the processing stations are shown the Figure 5. 
Table 9. Simulation time for each layout

\begin{tabular}{cc}
\hline Layout & $\begin{array}{c}\text { Total Simulation Time } \\
\text { (Days:Hours:Minutes:Seconds) }\end{array}$ \\
\hline Layout-1.1 & $1: 08: 56: 47.7476$ \\
\hline Layout-1.2 & $1: 06: 57: 44.8663$ \\
\hline Layout-1.3 & $17: 54: 10.1998$ \\
\hline
\end{tabular}

LAYOUT-1.1

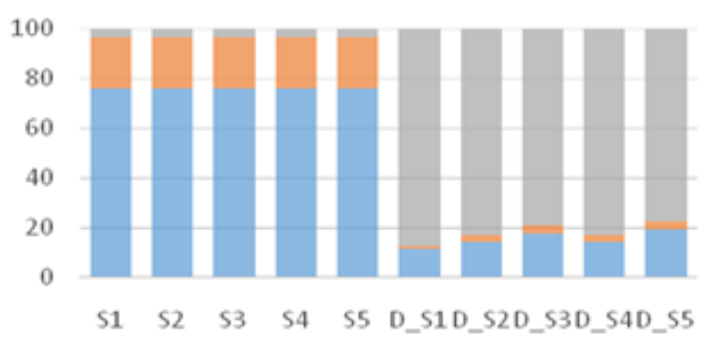

LAYOUT 1.2

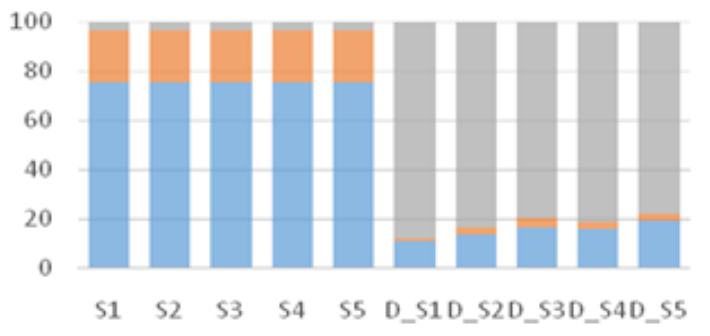

LAYOUT 1.3

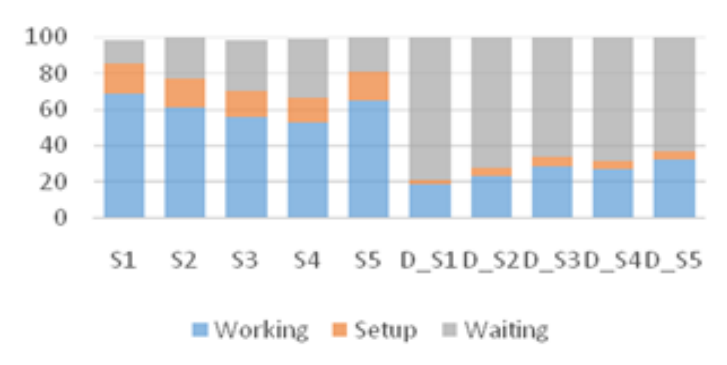

Figure 5. Production statistics of processing stations

\subsection{Observations from the layouts $2.1,2.2 \& 2.3$}

When the buffer is installed at stations its effect on the total simulation time is observed in this section. Table 10 shows the capacity of each buffer which is chosen by trial and error so that there will be no piling up of jobs at the stations. Since the bottle neck is in the first station the capacity of the buffer is more compared to other buffers in the layout $2.1 \& 2.2$. When there is no sequencing logic applied to the buffer the total MLT is shown in the Table 10. When the sequencing logic $1,2 \& 3$ is applied across the buffer the total simulation time \& its percentage of reduction compared to the initial layout is shown in the Table 11, Table $12 \&$ Table 13. The percentage of working, setup \& waiting portion of the processing stations after applying logic 1, $2 \& 3$ is shown the Figure 6, Figure 7, Figure 8.

Table 10. Reduction in the simulation time when buffer is added into the production line

\begin{tabular}{ccccc}
\hline Layout & Capacity of buffer1 & $\begin{array}{c}\text { Capacity of remaining } \\
\text { Buffer's }\end{array}$ & $\begin{array}{c}\text { MLT } \\
\text { (Days:Hours:Minutes:Sec) }\end{array}$ & Reduction in MLT (\%) \\
\hline 2.1 & 130 & 10 & $1: 08: 53: 45.1791$ & $0.15 \%$ \\
\hline 2.2 & 130 & & $1: 06: 55: 17.3857$ & $0.13 \%$ \\
\hline 2.3 & 100 & 100 & $16: 15: 50$ & $9.15 \%$ \\
\hline
\end{tabular}

Table 11. Capacity of buffer with the total reduction in total manufacturing time (Ascending order)

\begin{tabular}{ccccc}
\hline Layout & Capacity of Buffer1 & $\begin{array}{c}\text { Capacity of remaining } \\
\text { Buffer's }\end{array}$ & $\begin{array}{c}\text { MLT } \\
\text { (Days:Hours:Minutes:Sec) }\end{array}$ & Reduction in MLT (\%) \\
\cline { 1 - 3 } 2.1 & 130 & 10 & $1: 02: 38: 50.0049$ & $19.12 \%$ \\
\hline 2.2 & 130 & & $1: 00: 53: 22.9381$ & $19.61 \%$ \\
\hline 2.3 & 100 & 100 & $14: 51: 32.1709$ & $17.00 \%$ \\
\hline
\end{tabular}

Table 12. Capacity of buffer with the total reduction in total manufacturing time (Descending order)

\begin{tabular}{ccccc}
\hline Layout & $\begin{array}{c}\text { Capacity of } \\
\text { Buffer1 }\end{array}$ & $\begin{array}{c}\text { Capacity of remaining } \\
\text { Buffer's }\end{array}$ & $\begin{array}{c}\text { MLT } \\
\text { (Days:Hours:Minutes:Sec) }\end{array}$ & $\begin{array}{c}\text { Reduction in MLT } \\
(\%)\end{array}$ \\
\hline 2.1 & 130 & 10 & $1: 02: 38: 48.3418$ & $19.12 \%$ \\
\hline 2.2 & 130 & & $1: 00: 53: 49.4857$ & $19.59 \%$ \\
\hline 2.3 & 100 & 100 & $15: 43: 58.2299$ & $5.86 \%$ \\
\hline
\end{tabular}

Table 13. MLT when the sequencing logic 3 is applied the production line

\begin{tabular}{ccccc}
\hline Layout & Capacity of Buffer1 & $\begin{array}{c}\text { Capacity of remaining } \\
\text { Buffer's }\end{array}$ & $\begin{array}{c}\text { MLT } \\
\text { (Days:Hours:Minutes:Sec) }\end{array}$ & Reduction in MLT (\%) \\
\hline 2.1 & 130 & 10 & $1: 02: 38: 48.3418$ & $19.12 \%$ \\
\hline 2.2 & 130 & & $1: 00: 55: 06.4095$ & $19.52 \%$ \\
\hline 2.3 & 100 & 100 & $16: 52: 16.1824$ & $9.78 \%$ \\
\hline
\end{tabular}


The average percentage of increase in the working efficiency of the processing stations after the sequencing logic and average decrease in the setup is shown in the Table 14.

Table 14. Average working \& setup statistics

\begin{tabular}{ccc}
\hline Stations & $\begin{array}{c}\text { Increase in Working } \\
\text { Efficiency } \\
\text { of Processing Stations }\end{array}$ & $\begin{array}{c}\text { Decrease in Setup of } \\
\text { Machines } \\
\text { of Processing Stations }\end{array}$ \\
\hline S1 & 17.94 & 18.73 \\
\hline S2 & 17.94 & 18.73 \\
\hline S3 & 17.94 & 18.73 \\
\hline S4 & 17.94 & 18.73 \\
\hline S5 & 17.94 & 18.73 \\
\hline S6 & 2.63 & 0.68 \\
\hline S7 & 3.35 & 1.87 \\
\hline S & 4.07 & 2.96 \\
\hline S9 & 3.35 & 2.2 \\
\hline S10 & 4.55 & 2.66 \\
\hline
\end{tabular}
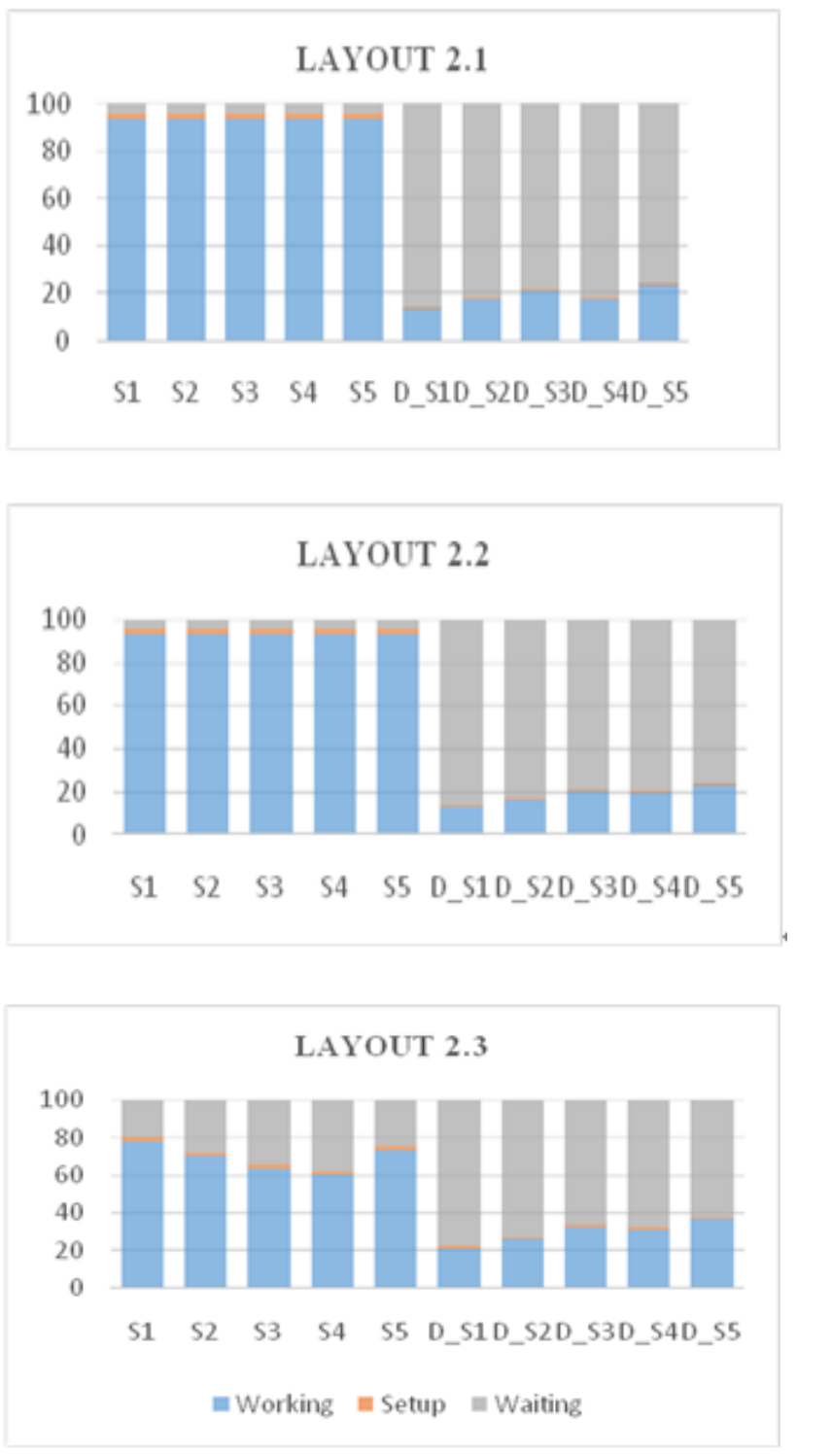

Figure 6. Production statistics after applying Logic-1

\section{LAYOUT 2.1}

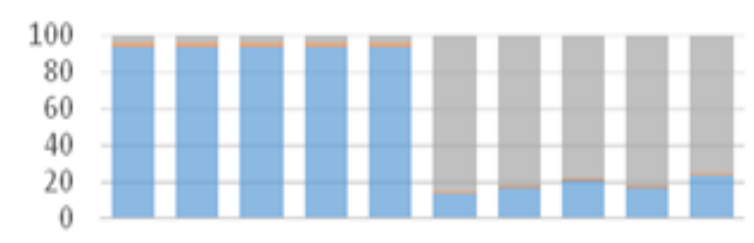

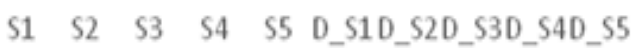

\section{LAYOUT 2.2}

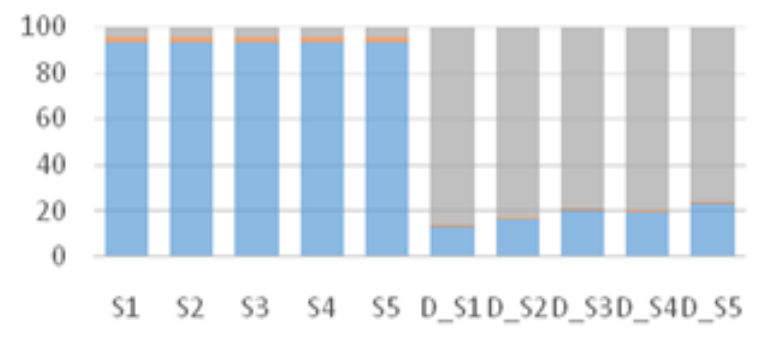

LAYOUT 2.3

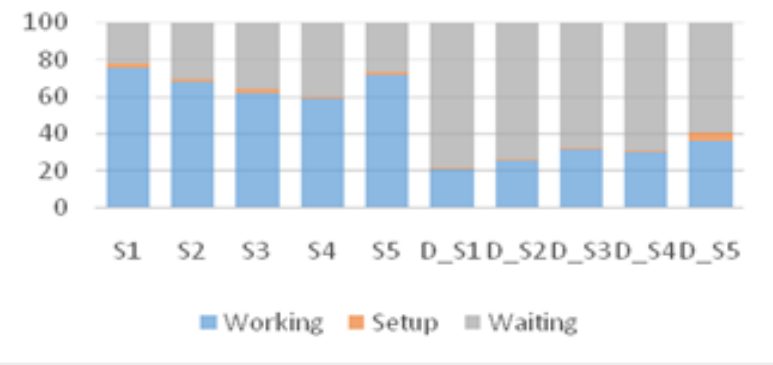

Figure 7. Production statistics after applying Logic-2

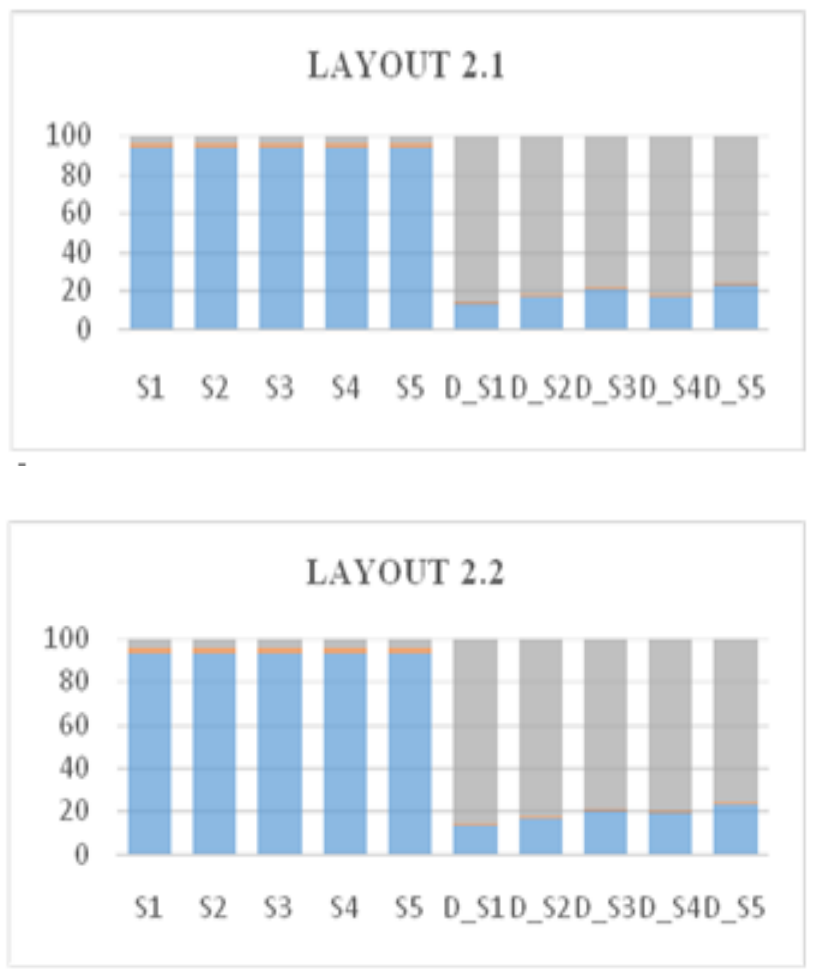




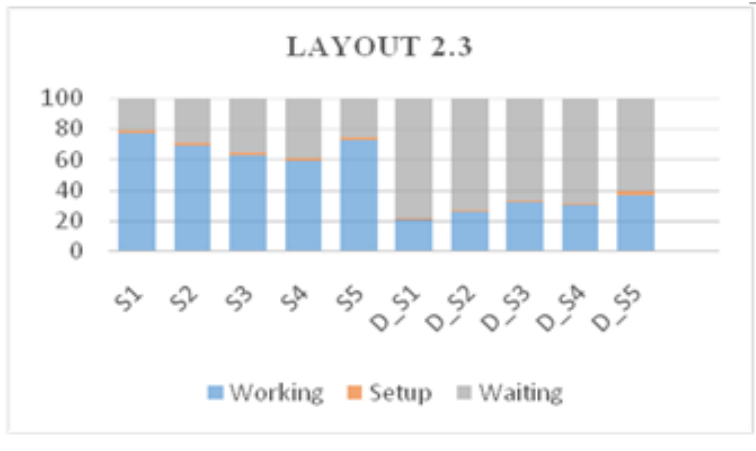

\subsection{The capacity of the buffer chosen using GA wizard}

The design of the storage space is the important aspect of any manufacturing industry, because it cost space, which is the critical aspect of manufacturing industry, so it is always desired to design for an optimum space area. The optimum value of the buffer space is designed by using GA Wizard which gives the optimum storage space designed through repeated iteration and also with the objective to minimize the time. The optimum capacity of each buffer using GA Wizard is shown in the Table 15.

Figure 8. Production statistics after applying Logic-3

Table 15. Optimum storage capacity of each buffer which uses GA Wizard

\begin{tabular}{|c|c|c|c|c|c|c|c|c|c|c|c|c|c|}
\hline \multirow[t]{2}{*}{ Layout } & \multirow[t]{2}{*}{ Logic } & \multicolumn{10}{|c|}{ Capacity of Buffer } & \multirow{2}{*}{$\begin{array}{c}\text { MLT } \\
\text { (Days:Hours:Minutes:Sec) }\end{array}$} & \multirow{2}{*}{$\begin{array}{c}\text { Reduction in MLT } \\
(\%)\end{array}$} \\
\hline & & 1 & 2 & 3 & 4 & 5 & 6 & 7 & 8 & 9 & 10 & & \\
\hline \multirow{3}{*}{2.1} & 1 & 134 & 18 & 60 & 38 & 133 & 13 & 10 & 11 & 47 & 7 & $1: 02: 38: 48.7147$ & 19.21 \\
\hline & 2 & 134 & 18 & 60 & 38 & 133 & 13 & 10 & 11 & 47 & 7 & 1:02:38:48.7147 & 19.21 \\
\hline & 3 & 139 & 118 & 125 & 15 & 6 & 49 & 50 & 4 & 34 & 33 & 1:02:35:45.0791 & 19.28 \\
\hline \multirow{3}{*}{2.2} & 1 & 130 & 10 & 10 & 10 & 10 & 6 & 6 & 6 & 6 & 6 & $1: 00: 53: 49.3857$ & 19.59 \\
\hline & 2 & 130 & 10 & 10 & 10 & 10 & 6 & 6 & 6 & 6 & 6 & 1:00:55:06.3095 & 19.52 \\
\hline & 3 & 139 & 118 & 125 & 15 & 6 & 41 & 42 & 4 & 29 & 27 & 1:00:49:32.4054 & 19.82 \\
\hline \multirow{3}{*}{2.3} & 1 & 140 & 60 & 145 & 85 & 42 & 10 & 10 & 12 & 10 & 36 & $15: 34: 57.3566$ & 12.96 \\
\hline & 2 & 14 & 46 & 150 & 109 & 86 & 30 & 30 & 3 & 16 & 30 & $15: 58: 50.3449$ & 10.74 \\
\hline & 3 & 21 & 65 & 9 & 65 & 66 & 12 & 12 & 24 & 29 & 33 & $14: 03: 35.0260$ & 21.47 \\
\hline
\end{tabular}

\subsection{Observation after upgrading the line with robot.}

The advantages of installing the robot in the layout to reduce the randomness in the setup since the accuracy and repeatability of the robot is good. Therefore, the production line with randomness is not considered for analysis. Its effect on the simulation for the layout $2.1 \& 2.3$ which uses GA Wizard for the capacity of buffer is shown in the Table 16.

Table 16. Simulation time when robot is used

\begin{tabular}{cccc}
\hline Layout & Logic & $\begin{array}{c}\text { MLT } \\
\text { (Days:Hours:Minutes:Sec) }\end{array}$ & $\begin{array}{c}\text { Reduction in } \\
\text { MLT } \\
(\%)\end{array}$ \\
\hline \multirow{3}{*}{2.1} & 1 & $1: 02: 44: 04.8624$ & 18.85 \\
\cline { 2 - 4 } & 2 & $1: 02: 44: 05.2794$ & 18.85 \\
\hline \multirow{3}{*}{2.3} & 3 & $1: 02: 39: 45.0791$ & 19.17 \\
\cline { 2 - 4 } & 1 & $15: 36: 42.2764$ & 12.8 \\
\cline { 2 - 4 } & 2 & $15: 23: 42.5800$ & 14.01 \\
\hline
\end{tabular}

\section{CONCLUSION}

In this paper different scenario of a diverging conveyor system which is commonly used in industries are studied and analysed. The effect of the buffer sequencing in reducing the production time of the line is shown. Three types of logic sequencing are applied in different scenarios of production line and it was observed that there is an average of $16.08 \%$ of reduction in time when the buffer is added into first five stations and $17.25 \%$ of reduction after the buffer was added to the remaining stations. Since the storage is an important aspect of the industries the use of genetic algorithm (GA Wizard) in effectively designing the storage space is considered and applied into the production line. With the use of GA Wizard, it has been observed that there is an average of $17.52 \%$ of reduction time with effective storage of buffer. Hence the model can be considered as the general model for optimizing production in the similar production industries.

\section{ACKNOWLEDGMENT}

The authors convey their sincere thankfulness to the referees and the editor for their constructive comments, which have immensely helped to bring this paper to the present form.

\section{REFERENCES}

[1] Udomkesmalee N, Daganzo CF. (1989). Impact of parallel processing on job sequences in flexible assembly systems. International Journal of Production Research 27(1):

73-89. https://doi.org/10.1080/00207548908942531

[2] Bolat A. (1997). Sequencing jobs for an automated manufacturing module with buffer. Eur. J. Oper. Res. 22(96): 622-635.

[3] Yu XF, Ram B. (2006) Bio-inspired scheduling for dynamic job shops with flexible routing and sequencedependent setups. International Journal of Production Research 44(22): 4793-4813. https://doi.org/10.1080/00207540600621094

[4] Matsuura H, Tsubone H, Kanezashi M. (2013). Sequencing, dispatching and switching in a dynamic manufacturing environment. International Journal of Production Research 31(7): 1671-1688. https://doi.org/10.1080/00207549308956816

[5] Hwang HC, Choi BK. (2014). Workflow-based dynamic scheduling of job shop operations. International Journal of Computer Integrated Manufacturing 20(6): 557-566. https://doi.org/10.1080/09511920601024179

[6] Vinod V, Sridharan R. (2013). Simulation-based 
metamodels for scheduling a dynamic job shop with sequence-dependent setup times. International Journal of Production 47(6):

$1425-1447$ https://doi.org/10.1080/00207540701486082

[7] Lou P, Ong SK, Nee AYC. (2014). Agent-based distributed scheduling for virtual job shops. International Journal of Production Research 48(13): 33889-3910. https://doi.org/10.1080/00207540902927918

[8] Renna P. (2014). Job shop scheduling by pheromone approach in a dynamic environment. International Journal of Computer Integrated Manufacturing 23(5): 412-424. https://doi.org/10.1080/09511921003642170

[9] Filho MAFB, Santos MO, Meneses CN, Paulo S. (2011). Asynchronous teams for joint lot-sizing and scheduling problem in flow shops. International Journal of Production Research 50(20): 5809-5822. https://doi.org/10.1080/00207543.2011.628955

[10] Carlo J, Vis I.FA. (2012). Sequencing dynamic storage systems with multiple lifts and shuttles. Int. J. Production Economics 140: 844-853.

[11] Trentesaux D, Pach C, Bekrar A, Sallez Y, Berger T, Bonte T, Leitão P, Barbosa J. (2013). Control Engineering Practice Benchmarking fl exible job-shop scheduling and control systems. Control Eng. Pract. 21(9): 1204-1225. https://doi.org/10.1016/j.conengprac.2013.05.004

[12] Taylor P, Mauergauz Y. (2014). Dynamic group job shop scheduling Dynamic group job shop scheduling. International Journal of Management Science and Engineering Management 37-41.

[13] Saidi-mehrabad M, Dehnavi-arani S, Evazabadian F, and Mahmoodiana V. (2015). An Ant Colony Algorithm (ACA) for solving the new integrated model of job shop scheduling and conflict-free routing of AGVs. Comput. Ind. $\quad$ Eng. 86: 2-13 https://dx.doi.org/10.1016/j.cie.2015.01.003

[14] Strohhecker J, Hamann M, Thun J. (2016). Loading and sequencing heuristics for job scheduling on two unrelated parallel machines with long, sequencedependent set-up times. International Journal of Production Research 54(22): 6747-66767. https://dx.doi.org/10.1080/00207543.2016.1173248

[15] Kim J., Park J., and Lee D. (2017). Iterated greedy algorithms to minimize the total family flow time for jobshop scheduling with job families and sequencedependent set-ups. Eng. Optim. 49(10): 1719-732.
https://doi.org/10.1080/0305215X.2016.1261247

[16] Nasiri MM, Yazdanparast R, Jolai F. (2017). A simulation optimisation approach for real-time scheduling in an open shop environment using a composite dispatching rule. Int. J. Comput. Integr. Manuf., $\quad 30(12)$ : 1239-1252. https://doi.org/10.1080/0951192X.2017.1307452

[17] Leisten R. (1990). Flowshop sequencing problems with limited buffer storage. International Journal of Production Rearch 28(11): 2085-2100. https://doi.org/10.1080/00207549008942855

[18] Park T, Steudel HJ. (1991). A model for determining job throughput times for manufacturing flow line workcells with finite buffers. 29(10): 2025-2041. https://doi.org/10.1080/00207549108948065

[19] Bolat A. (1994). Sequencing jobs on an automobile assembly line : Objectives and procedures. International Journal of Production Research 32(5): 1219-1236. https://doi.org/10.1080/00207549408956996

[20] Sharadapriyadarshini B, Rajendran C. (1996). "Formulations and heuristics for scheduling in a bufferconstrained flowshop and flowline-based manufacturing cell with different buffer-space requirements for jobs: Part 1. International Journal of Production Rearch 34(12): 3465-3485. https://doi.org/10.1080/00207549608905100

[21] Solimanpur M, Elmi A. (2011). A tabu search approach for group scheduling in buffer- constrained flow shop cells. International Journal of Computer Integrated Manufacturing 24(3): 257-268. https://doi.org/10.1080/0951192X.2011.552527

[22] Kamali J, Moodie CL, Salvendy G. (1982). A framework for integrated assembly systems: humans, automation and robots. International Journal of Production Rearch 20(4):

431-448 https://doi.org/10.1080/00207548208947777

[23] Buzacott JA. (1990). Abandoning the moving assembly line : models of human operators and job sequencing. International Journal of Production Research 28(5): 821 839.

[24] Ho JKL, Ranky PG. (1997) Object oriented modelling and design of reconfigurable conveyors in flexible assembly systems. International Journal of Computer Integrated Manufacturing 10(5): 360-379. https://doi.org/10.1080/095119297131101 